\title{
PENGARUH MEDIA SOSIAL WHATSAPP TERHADAP KINERJA GURU DI MASA PANDEMI COVID-19
}

\author{
Suyit Ratno, Rizki Aulia Elissa \\ Surel: suyit85@unimed.ac.id
}

\begin{abstract}
This research aims to determine whether the use of WhatsApp social media during the Covid19 pandemic has an effect on teacher performance at UPT SPF SD Negeri 101877 Tanjung Morawa. The research method is a correlational research method. The subjects of this study were teachers at UPT SPF SD Negeri 101877 Tanjung Morawa in 2020/2021. The research sample was 20 teachers using the population research method. Data from this survey was collected through a questionnaire. The questionnaire used was tested for validity and reliability. While the data analysis method used is product moment correlation. Based on the calculation results obtained $r$ count of 9.566, and these results are compared with $r$ table at a significance level of 5\% (2.086). This means that the use of WhatsApp social media affects the performance of teachers UPT SPF SD Negeri 101877 Tanjung Morawa during the covid19 pandemic. Meanwhile, the use of WhatsApp accounted for $69.1 \%$ of teacher performance, with the remaining $30.9 \%$ influenced by other factors.
\end{abstract}

Keywords: WhatsApp social media, teacher performance, covid19 pandemic

\begin{abstract}
ABSTRAK
Penelitian ini bertujuan untuk mengetahui apakah penggunaan media sosial WhatsApp pada masa pandemi Covid19 berpengaruh terhadap kinerja guru di UPT SPF SD Negeri 101877 Tanjung Morawa . Metode penelitian yang digunakan adalah metode penelitian jenis penelitian korelasional. Subyek penelitian ini adalah guru UPT SPF SD Negeri 101877 Tanjung Morawa Tahun 2020/2021. Sampel penelitian adalah 20 guru dengan menggunakan metode penelitian populasi. Data dari survei ini dikumpulkan melalui kuesioner. Kuesioner yang digunakan diuji validitas dan reliabilitasnya. Sedangkan metode analisis data yang digunakan adalah korelasi product moment. Berdasarkan hasil perhitungan diperoleh $\mathrm{r}$ hitung sebesar 9,566, dan hasil tersebut dibandingkan dengan $\mathrm{r}$ tabel pada taraf signifikansi 5\% $(2,086)$. Artinya > penggunaan media sosial WhatsApp mempengaruhi kinerja guru UPT SPF SD Negeri 101877 Tanjung Morawa selama masa pandemi covid19. Sementara itu, penggunaan WhatsApp menyumbang $69,1 \%$ dari kinerja guru, dengan 30,9\% sisanya dipengaruhi oleh faktor lain.
\end{abstract}

Kata Kunci : Media Sosial Whatsapp, Kinerja Guru, Pandemi Covid-19

\section{PENDAHULUAN}

Indonesia saat ini sedang mengalami kasus corona atau Covid
19, virus corona 2019 menyebabkan gejala flu biasa, dan penyakit yang disebabkan oleh COVID-19 sejauh ini 
menunjukkan angka kematian yang sangat tinggi. Virus ini melanda seluruh dunia, termasuk Indonesia. Lebih dari setahun setelah pandemi Covid-19, pemerintah telah menetapkan banyak pedoman untuk mengurangi tingkat infeksi, termasuk jarak sosial, bekerja dari rumah( WFH) dan pembatasan kegiatan masyarakat (PPKM). Kegiatan berbagai lembaga dan penutupan pertemuan massal. Tanpa terkecuali, hal ini berdampak besar bagi kehidupan masyarakat di dunia pendidikan. Salah satu kebijakan pemerintah di bidang pendidikan adalah pendidikan jarak jauh (PJJ).

Pendidikan adalah usaha sadar dan sistematis. Dengan kata lain, proses pendidikan di sekolah bukanlah proses yang asal-asalan, melainkan suatu proses yang bertujuan untuk memastikan bahwa guru dan siswa melakukan segala sesuatu yang mereka lakukan untuk mencapai tujuannya. Pendidik harus sangat antusias dalam melatih, mengajar dan melatih peserta didik agar dapat melaksanakan proses pendidikan sesuai dengan yang diinginkan dan yakin dapat mencapai potensi dirinya.

Guru harus mampu menciptakan metode pengajaran yang kreatif, inovatif dan bermakna untuk mencapai tujuan pembelajaran yang diharapkan. Guru sebagai pengelola pembelajaran merupakan kunci terpenting keberhasilan proses pembelajaran. Dalam kegiatan pendidikan, guru harus berinteraksi dengan baik dengan siswa. Guru harus arif dan bijaksana serta tidak merugikan siswanya. Proses pendidikan dan pembelajaran menuntut pendidik untuk dekat dengan anak didik sehingga dapat mencapai tujuan belajarnya dengan benar. Siswa menikmati dan memahami proses belajar dan mengajar dengan lambat, tanpa mereka langsung mengerti apa yang diajarkan guru dan tanpa membebani mereka.

WhatsApp memungkinkan Anda untuk mengirim pesan kepada orang lain dalam bentuk teks, audio, file dokumen, foto, dan video. Selain membuat obrolan pribadi, Anda juga dapat membuat obrolan grup yang menyertakan beberapa pengguna WhatsApp. Misalnya, Anda ingin membuat obrolan grup dengan anggota keluarga besar untuk memfasilitasi komunikasi antar anggota keluarga jauh. Saat ini sudah umum menggunakan WhatsApp sebagai alat pembelajaran untuk kursus/pelajaran (baik obrolan grup maupun obrolan tatap muka), seminar, dan lokakarya online. Cukup buat obrolan grup, undang peserta ke grup dan mulai kelas. Anda dapat menggunakan WhatsApp sebagai tempat untuk menyatukan komunitas online Anda. Anda dapat terhubung dengan anggota komunitas lain, yang memfasilitasi penyebaran informasi dan komunikasi. Selain mengirim pesan, Anda juga dapat melakukan panggilan telepon dan panggilan video ke pengguna lain. Untuk memastikan panggilan video dan audio yang lancar dan bebas noise, 
pastikan koneksi internet Anda stabil.

WhatsApp banyak digunakan untuk kegiatan bisnis seperti promosi, informasi dan pemesanan.

Kinerja guru adalah

kemampuan seorang guru untuk menyelesaikan suatu tugas atau tugas dalam melaksanakan suatu pekerjaan. Kinerja guru adalah proses pembelajaran yang dirancang untuk membuat kelas yang ada menjadi lebih efektif. Dengan demikian, tujuan pendidikan yang telah ditetapkan dapat tercapai. Kinerja guru yang tinggi sangat penting untuk meningkatkan hasil belajar. Ketika datang ke deskripsi tugas, kinerja berkaitan dengan pengetahuan, keterampilan dan karakteristik perilaku guru. Dengan kata lain, pengaruh seorang guru terungkap tidak hanya dalam hasil pekerjaan tetapi juga dalam perilaku dalam kinerja pekerjaan. Pendidikan yang efektif dan efisien menghasilkan sumber daya manusia atau lulusan yang efisien dan efektif sesuai dengan tujuan yang telah ditetapkan. Oleh karena itu, perlu adanya peningkatan kinerja guru dalam proses pembelajaran agar lebih mengembangkan kegiatan yang ada berdasarkan keterampilan daripada keturunan atau keturunan, dan dengan tetap menjaga kualitas, inisiatif, kreativitas, ketekunan dan produktivitas.

\section{METODE PENELITIAN}

Penelitian ini merupakan penelitian asosiasi, yaitu penelitian yang bertujuan untuk menganalisis hubungan antara variabel yang satu dengan variabel yang lain, atau bagaimana variabel yang satu mempengaruhi variabel yang lain, atau apakah variabel yang satu mempengaruhi variabel yang lain. Analisis data kuantitatif menggunakan metode korelasi. Sebagai populasi sebanyak 20 orang guru di UPT SPF SD Negeri 101877 Tanjung Morawa di masa pandemi covid-19. Jenis angket yang digunakan adalah angket tertutup dimana responden diberikan pertanyaan dalam format pilihan ganda dengan skor Likert.

\section{HASIL PENELITIAN DAN PEMBAHASAN}

Pada bagian ini akan dideskripsikan gambaran mengenai pengaruh media sosial whatsapp terhadap kinerja guru di UPT SPF SD Negeri 101877 Tanjung Morawa di masa pandemi covid-19.

Pengaruh media sosial whatsapp dan kinerja guru pada penelitian ini diukur dengan 20 soal pertanyaan. Hasil tanggapan terhadap variabel tersebut adalah sebagai berikut: 
SCHOOL EDUCATION JOURNAL VOLUME 11 NO. 4 DESEMBER 2021

Tabel 1. Analisis Persentase Skor Responden Terhadap Soal

\begin{tabular}{|c|c|c|c|c|c|c|}
\hline \multirow{2}{*}{ Soal } & \multicolumn{5}{|c|}{ Skor } & \multirow{2}{*}{ Jumlah } \\
\hline & 5 & 4 & 3 & 2 & 1 & \\
\hline 1 & $7(35 \%)$ & $7(35 \%)$ & $4(20 \%)$ & $2(10 \%)$ & $0(0 \%)$ & $20(100 \%)$ \\
\hline 2 & $11(55 \%)$ & $9(45 \%)$ & $0(0 \%)$ & $0(0 \%)$ & $0(0 \%)$ & $20(100 \%)$ \\
\hline 3 & $4(20 \%)$ & $6(30 \%)$ & $6(30 \%)$ & $4(20 \%)$ & $0(0 \%)$ & $20(100 \%)$ \\
\hline 4 & $2(10 \%)$ & $7(35 \%)$ & $6(30 \%)$ & $5(25 \%)$ & $0(0 \%)$ & $20(100 \%)$ \\
\hline 5 & $6(30 \%)$ & $3(15 \%)$ & $6(30 \%)$ & $4(20 \%)$ & $1(5 \%)$ & $20(100 \%)$ \\
\hline 6 & $7(35 \%)$ & $10(50 \%)$ & $2(10 \%)$ & $1(5 \%)$ & $0(0 \%)$ & $20(100 \%)$ \\
\hline 7 & $7(35 \%)$ & $7(35 \%)$ & $3(15 \%)$ & $3(15 \%)$ & $0(0 \%)$ & $20(100 \%)$ \\
\hline 8 & $7(35 \%)$ & $11(55 \%)$ & $1(5 \%)$ & $1(5 \%)$ & $0(0 \%)$ & $20(100 \%)$ \\
\hline 9 & $10(50 \%)$ & $6(30 \%)$ & $2(10 \%)$ & $2(10 \%)$ & $0(0 \%)$ & $20(100 \%)$ \\
\hline 10 & $8(40 \%)$ & $7(35 \%)$ & $4(20 \%)$ & $1(5 \%)$ & $0(0 \%)$ & $20(100 \%)$ \\
\hline 11 & $8(40 \%)$ & $10(50 \%)$ & $1(5 \%)$ & $1(5 \%)$ & $0(0 \%)$ & $20(100 \%)$ \\
\hline 12 & $1(5 \%)$ & $11(55 \%)$ & $5(25 \%)$ & $3(15 \%)$ & $0(0 \%)$ & $20(100 \%)$ \\
\hline 13 & $4(20 \%)$ & $11(55 \%)$ & $2(10 \%)$ & $3(15 \%)$ & $0(0 \%)$ & $20(100 \%)$ \\
\hline 14 & $8(40 \%)$ & $9(45 \%)$ & $1(5 \%)$ & $2(10 \%)$ & $0(0 \%)$ & $20(100 \%)$ \\
\hline 15 & $2(10 \%)$ & $4(20 \%)$ & $12(60 \%)$ & $2(10 \%)$ & $0(0 \%)$ & $20(100 \%)$ \\
\hline 16 & $3(15 \%)$ & $6(30 \%)$ & $9(45 \%)$ & $2(10 \%)$ & $0(0 \%)$ & $20(100 \%)$ \\
\hline 17 & $3(15 \%)$ & $4(20 \%)$ & $7(35 \%)$ & $5(25 \%)$ & $1(5 \%)$ & $20(100 \%)$ \\
\hline 18 & $5(25 \%)$ & $11(55 \%)$ & $3(15 \%)$ & $1(5 \%)$ & $0(0 \%)$ & $20(100 \%)$ \\
\hline 19 & $3(15 \%)$ & $7(35 \%)$ & $8(40 \%)$ & $2(10 \%)$ & $0(0 \%)$ & $20(100 \%)$ \\
\hline 20 & $5(25 \%)$ & $6(30 \%)$ & $6(30 \%)$ & $3(15 \%)$ & $0(0 \%)$ & $20(100 \%)$ \\
\hline Jumlah & 111 & 152 & 88 & 47 & 2 & 400 \\
\hline Rata-rata & 5,55 & 7,6 & 4,4 & 2,35 & 0,1 & 20 \\
\hline Persen & $28 \%$ & $38 \%$ & $22 \%$ & $12 \%$ & $1 \%$ & $100 \%$ \\
\hline
\end{tabular}

\section{Persentase Rata-Rata Butir Soal}

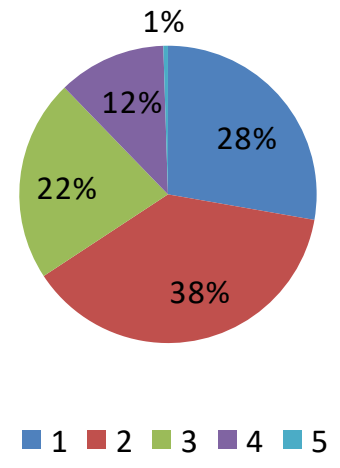

Gambar 1. Diagram lingkaran Persentase Rata-Rata Butir Soal Pengaruh Media Sosial Whatsapp terhadap Kine rja Guru 
Tabel 2. Uji Hipotesis

\begin{tabular}{|c|c|c|c|c|c|c|}
\hline \multicolumn{7}{|c|}{ Coefficients $^{a}$} \\
\hline \multirow{2}{*}{\multicolumn{2}{|c|}{ Model }} & \multicolumn{2}{|c|}{ Unstandardized Coefficients } & \multirow{2}{*}{$\begin{array}{c}\begin{array}{c}\text { Standardized } \\
\text { Coefficients }\end{array} \\
\text { Beta }\end{array}$} & \multirow[b]{2}{*}{$\mathrm{t}$} & \multirow[b]{2}{*}{ Sig. } \\
\hline & & $\mathrm{B}$ & Std. Error & & & \\
\hline \multirow[t]{2}{*}{1} & (Constant) & 7,522 & 3,362 & & 2,237 & 031 \\
\hline & VAR00001 & ,905 & ,095 & ,831 & 9,566 &, 000 \\
\hline
\end{tabular}

a. Dependent Variable:VAR00002

Hasil pengujian hipotesis, nilai hitung $\mathrm{t}$ adalah 9,566 > t tabel 2,021, dan taraf signifikansi 0,000 lebih kecil dari 0,05 , artinya hipotesis penelitian ini menolak Ho dan menerima Ha. Oleh karena itu, dapat disimpulkan bahwa media sosial WhatsApp berpengaruh positif terhadap kinerja guru.

Tabel 3. Koefisien Determinasi

\begin{tabular}{l|r|r|r|r}
\multicolumn{7}{c|}{ Model Summary } \\
\hline Model & $\mathrm{R}$ & $\mathrm{R}$ Square & $\begin{array}{c}\text { Adjusted R } \\
\text { Square }\end{array}$ & $\begin{array}{c}\text { Std. Error of the } \\
\text { Estimate }\end{array}$ \\
\hline 1 &, $831^{\mathrm{a}}$ &, 691 &, 683 & 2,452 \\
\hline
\end{tabular}

a. Predictors: (Constant), VAR00001

b. Dependent Variable: VAR00002

\begin{abstract}
Hasil perhitungan regresi linear sederhana dapat diketahui bahwa koefisien determinasi ( $\mathrm{R}$ Square) yang diperoleh sebesar 0,691. Hal ini berarti $69,1 \%$ variabel kinerja guru dapat dijelaskan oleh variabel media sosial whatsapp, sedangkan sisanya 30,9\% diterangkan oleh variabel lain yang tidak diajukan dalam penelitian ini.
\end{abstract}

\section{Pembahasan}

Media sosial WhatsApp digunakan guru UPT SPF 101877 Tanjung Morawa sebagai media pembelajaran informasi di masa pandemi COVID-19. WhatsApp merupakan media bagi guru untuk bertanya dalam menyelesaikan pekerjaannya, berdiskus dengan rekan dan saling berinteraksi dan berhubungan dengan aktivitas mengajar. Guru akan mengirimkan materi pembelajaran. Materi pembelajaran yang digunakan biasanya berupa video pembelajaran dan file yang disesuaikan dengan kebutuhan siswa. Setelah guru mengirimkannya ke grup WhatsApp. Siswa memiliki kesempatan untuk memahami sepenuhnya materi yang diberikan oleh WhatsApp, dan guru dapat memilih untuk bertanya kepada siswa atau tidak memahami materi yang ditentukan.

Keunggulan WhatsApp tidak bisa dipungkiri di sini. Mungkin kelebihan WhatsApp ini juga menjadi alasan penggunaannya yang terbilang lama. Pasalnya, kelebihan WhatsApp 
adalah sangat mudah digunakan bahkan untuk para pengguna pemula. Dalam hal ini, manfaat WhatsApp tidak terbatas pada merek ponsel cerdas dan sistem operasi tertentu. Hampir semua merek smartphone dan sistem operasi kompatibel dengan aplikasi WhatsApp.

\section{SIMPULAN}

Berdasarkan penelitian yang dilakukan maka $\mathrm{t}$ hitung $>\mathrm{t}$ tabel, ini berarti bahwa penggunaan media sosial Whatsapp akan mempengaruhi kinerja guru UPT SPF SD Negeri 101877 Tanjung Morawa selama masa pandemi Covid19. Di sisi lain, penggunaan media WhatsApp memberikan kontribusi sebesar 69,1\% terhadap kinerja guru, sedangkan sisanya sebesar 30,9\% dipengaruhi oleh faktor lain.

\section{DAFTAR RUJUKAN}

Amelia, K. 2017. Pengaruh media jejaring sosial facebook terhadap kinerja Guru di madrasah aliyah negeri 1 bukittinggi. Riau: Jurnal Ilmu Komputer dan Bisnis, 8(1), 1881-1889

Elianur, C. 2017. Pemanfaatan aplikasi whatsapp sebagai sarana diskusi antara pengawas dan guru pendidikan agama Islam. Jurnal As-Salam, 1(2), 114.

Kusuma, J. W., \& Hamidah, H. 2020. Perbandingan Hasil Belajar Matematika Dengan Penggunaan Platform Whatsapp Group Dan Webinar Zoom Dalam Pembelajaran Jarak Jauh Pada
Masa Pandemik Covid 19.

JIPMat, $5(1)$. https://doi.org/10.26877/jipmat.v 5 il. 5942

Hidayatullah Pangestika, N. L. 2018. Pengaruh pemanfaatan media sosial whatsapp terhadap penyebaran informasi pembelajaran di SMA Negeri 5 Depok. Jakarta: FITK UIN Syarif Jakarta

Sugiyono. 2014. Metode Penelitian Kuantitatif dan $R \& D$. Alfabeta

Suryadi, E., Ginanjar, M. H., \& Priyatna, M. 2018. Penggunaan sosial media whatsapp pengaruhnya terhadap disiplin belajar peserta didik pada mata pelajaran pendidikan agama Islam (Studi kasus di SMK Analis Kimia YKPI Bogor). Edukasi Islami: Jurnal Pendidikan Islam, 7(01), 1-22.

Yensy, N. A. 2020. Efektifitas pembelajaran statistika matematika melalui media whatsapp group ditinjau dari hasil belajar mahasiswa (masa pandemik Covid 19). Jurnal Pendidikan Matematika Raflesia, 05(02), 65-74. https://ejournal.unib.ac.id/index.p hp/jpmr

Zahroh, F. 2021. Pengaruh penggunaan media sosial whatsapp terhadap motivasi belajar siswa kelas IV SDN Pakong 1 Pamekasan di masa pandemi covid-19. Madura: Edukasi Tematik: Jurnal Pendidikan Guru Sekolah Dasar, 2 (1), 12-21. 